\title{
THE PERCEPTION OF ACCOUNTING EDUCATORS AND PRACTITIONERS TOWARDS THE PRACTICES OF CREATIVE ACCOUNTING
}

\author{
Dr. Adeosun, O. A. \\ Department of Accounting, Bamidele Olumilua University of Education, Science and Technology, \\ Ikere Ekiti, Ekiti State, Nigeria
}

Adekanmbi, J. A.

Department of Accounting, Bamidele Olumilua University of Education, Science and Technology, Ikere Ekiti, Ekiti State, Nigeria

Ogunleye, W. A.

Department of Vocational and Technical Education, Faculty of Education, Ekiti State University, Ado

Ekiti, Ekiti State, Nigeria

Article DOI: https://doi.org/10.36713/epra6054

\begin{abstract}
The study examined perception of Accounting Educators and Practitioners towards the practices of creative accounting. The study adopted descriptive research of a survey type. The population of the study comprises 187 Accounting Educators (academic staff) and practitioners at Afe Babalola University, Ado Ekiti and Federal Polytechnic, Ado Ekiti. The sample of the study was 60 respondents selected using a purposive random sampling technique. Questionnaire was the instrument used for data collection. Face validity of the instrument was ensured by the experts in the Department of Accounting. The reliability of the instrument was determined through a pilot-test conducted on the instrument. The reliability coefficient of 0.85 was obtained using the Cronbach alpha coefficient. The research questions were answered using mean scores and standard deviation and ANOVA test was used to test the hypotheses formulated at 0.05 level of significance. The study revealed that practices of creative accounting affect all the characteristics of accounting information as well as users' investment decisions and the integrity of the practitioners. In conclusion, accounting educators and practitioners indicated that creative accounting negatively affect the accounting information and the profession. Therefore, the study recommended that accounting bodies should take strict measures to curb creative accounting practices among accounting practitioners, to restore integrity and users' confidence in accounting information. Also, a monitoring group should be in place to check the draft of accounting information prepared by any organization this would be required to prepare a financial statement before being finally published for public consumption.
\end{abstract}

KEYWORDS: Accounting Operation, Accounting, Auditing, Investment Decision, Financial Reporting 


\section{SJIF Impact Factor 2021: 7.13| ISI I.F.Value:1.241| Journal DOI: 10.36713/epra2016 EPRA International Journal of Research and Development (IJRD)}

\section{INTRODUCTION}

The practice of creative accounting among accountants has called for a debate in recent times due to the failure of many business organizations, banking industry, and corporate organizations. The practice made many investors, shareholders, creditors, lenders, public, and others to doubt the reliability of accounting information which is primarily produced by accounting practitioners to show true and fair state of financial reports of an entity which would enable the users make appropriate decisions. Furthermore, the creative accounting practices have caused a lot of criticism to the accounting profession all over the world because it allows different policies and professional judgments in determining the methods of measurement. For instance, the consequence of creative accounting method led to the collapse/breakdown of many companies such as Arther Anderson, Enron, WorldCom, Parmalat, Tyco, Cadbury Nigeria Plc, Unilever, African Petroleum and Afribank in Nigeria etc. It has not only cost billions of dollars/naira loss to the stakeholders but has also damaged the accounting profession as a result of misrepresentation caused by cooked, padded or window dressed accounting information.

However, it is sad that accounting information is no longer useful despite the laudable roles of auditing. This is due to the practice of creative accounting which has led many investors and other users of accounting information to lose their investments and jobs as well as doubt the truth and fairness of the accounting information prepared by accounting practitioners. Hence, creative accounting seems to be an intentional manipulation of the accounting information in order to influence certain competitors on the capital market for self-interests. Victoria, (2014) opined that the only way accountants are using to support the manager as well as to promote and support the company's image is through creative accounting, manager use the manipulated accounting information to support his self-interest. Yadav (2013) believed that creative accounting is the accounting practices that may or may not follow the letter of the rules of accounting standard practices but certainly deviate from those rules and regulations in order to systematically achieve misrepresentation of the true and fair income, liabilities and assets of corporations or organizations.

From these views, creative accounting can be regarded as a process whereby accountant and auditors use their knowledge of accounting rules to manipulate the accounting information of a business organization/entity. Salome, (2012) having studied strategies used by accountants in Nigeria to practice creative accounting, revealed that accountants use profit eroding mechanisms which lead to drastic consequences like corporate scandals and collapse both international and locally. Akenbor and Ibanichuka (2012) affirmed that creative accounting practices in the real world experience has become a curse because most cases are practiced in an undesirable way to attract investors by presenting sometimes misleading, deceptive and exaggerated state of an organization's financial affairs. Based on the above, it is obvious that the accounting information is no longer reliable irrespective of the firm, management, accountants that prepared it or auditors that certified such accounting information. This has affected accounting profession as a whole. Therefore, this study aims to examine the perception of accounting educators and practitioners toward the practices of creative accounting.

\section{STATEMENT OF THE PROBLEM}

There is no doubt that applications of creative accounting methods have affected quality of accounting information. Although creative accounting methods is employed by practitioners and companies to achieve a specific selfish purpose. Due to creative accounting practices and self interest, the following are the examples of failed auditing firms and companies both internationally and locally, Enron (2001), WorldCom (2002) in USA, Saytam Computer Services Limited (2009) in India, and American Insurance Group (2005). Also in the case of Nigeria, Akintola Williams and Deloitte were indicted for facilitating the falsification of accounts of Afribank Plc and Main Stream Bank PLC and for deliberate overstating the profits of Cadbury Nigeria PLC. Oluwagbuyi and Olowolaju (2013), Bankole, et al (2018) reported that between 1990 and 1994, Nigeria lost more than N6 billion ( $\$ 42.9$ million) within the banking sector alone due to creative accounting practices.

The problem of this study is that many users of accounting information no longer value the accounting information since it could not be safely used to make investment decision. In addition, on the side of auditors, creative accounting shows that there is collaboration between auditors, management and manager of an entity which is against professional ethics of auditors. This collaboration is affecting auditor's responsibility to report on the accounts, to identify whether they have been properly prepared, and to provide an opinion on whether they show a true and fair view (Kevin, in Ismael, 2017). If this were not so why do auditors fail to raise eye brow when they knew that creative accounting can decrease the value, reliability, relevance and truthfulness of accounting information? Enron collapsed because Arthur Anderson as an auditor did not take absolute responsibility to 


\section{SJIF Impact Factor 2021: 7.13| ISI I.F.Value:1.241| Journal DOI: 10.36713/epra2016 \\ ISSN: 2455-7838(Online) \\ EPRA International Journal of Research and Development (IJRD)}

prevent the company from creative accounting (Ihsan, in Ismael, 2018). Lastly, should the practices of creative accounting continue in accounting profession or not? Therefore, this study aims to examine the perception of accounting educators and practitioners towards the practices of creative accounting at Afe Babalola University, Ado Ekiti and Federal Polytechnic, Ado Ekiti.

\section{PURPOSE OF THE STUDY}

This study examined the perception of accounting educators and practitioners towards the practices of creative accounting. Specifically, the study;

1. examined the awareness of the term creative accounting among academic staff and accounting practitioners

2. identified the creative accounting techniques used to influence corporate financial statements

3. examine the extent to which creative accounting practices affect the characteristics of accounting information

4. examined the opinion of accounting educators and practitioners toward the practices of creative accounting

\section{RESEARCH QUESTIONS}

The following research questions were raised to guide the study

1. Are you aware of the term creative accounting?

2. What are the creative accounting techniques used in accounting profession?

3. To what extent do creative accounting practices affect the characteristics of accounting information?

4. What is the opinion of accounting educators and practitioners toward the practices of creative accounting?

\section{RESEARCH HYPOTHESES}

The following research hypotheses were formulated for the study

1. There is no significant difference between accounting educators and practitioners' responses on creative accounting techniques used in accounting profession.

2. There is no significant difference between accounting educators and practitioners' responses on the extent to which creative accounting practices affect the characteristics of accounting information

3. There is no significant difference between accounting educators and practitioners' responses on the opinion of accounting educators and practitioners toward the practices of creative accounting in accounting profession

\section{LITERATURE REVIEW \\ Conceptual Framework \\ Creative Accounting}

The term creative accounting means different things to different people, it can be referred to as systematic misrepresentation of the true income and assets, as well as cosmetic accounting, window dressing, financial engineering, cooking of account, big bath accounting, massaging the numbers, manipulating of accounting information to attract investors. However, some believe that creative accounting is a tool for obtaining "true and fair view". In the view of Shah, Butt, and Tariq (2011), creative accounting can be regarded as intentional influence applied on financial reports to meet the impression of managers to stakeholders by a view other than the actual financial position of the company/organization based on accounting knowledge and discretion within the jurisdiction of laws set up by accounting regulatory bodies. Creative accounting according to Naser in Gabriëls and Van De Wiele (2005) is the process of manipulating accounting figures by taking advantage of the loopholes in accounting rules, and the choices of measurement and disclosure practices in them to change financial statements from what they are supposed to be, to what accountants would prefer to see reported. They further opined that it is a process by which transactions are structured in order to produce the desired accounting results rather than reporting transactions in a neutral and consistent way.

Furthermore, Tassadaq and Malik (2015) asserted that creative accounting is the art of faking or presenting the balance sheet, and the art of saving money. Adetayo and Ajiga, (2017) revealed that the practices has resulted to corporate scandals which include massive loss of investors fund, loss of jobs, disruption of capital market and reduction in the National Gross Domestic Product (GDP). Sanusi and Izedonmi, (2014) considered creative accounting as a serious crime and unethical practices that accounting bodies, law courts as well as other regulatory authorities need to adopt strict measures to stop. It could be deduced from the above that creative accounting is corrupted practices in accounting profession.

\section{Empirical Reviews}

Tassadaq and Malik (2015) investigated Creative accounting and financial reporting: model development and empirical testing in the industrial 


\section{SJIF Impact Factor 2021: 7.13| ISI I.F.Value:1.241| Journal DOI: 10.36713/epra2016 \\ ISSN: 2455-7838(Online) \\ EPRA International Journal of Research and Development (IJRD)}

Volume: 6 | Issue: 3 | March 2021

- Peer Reviewed Journal

sector of Pakistan. The questionnaire was the major instrument used to collect data in their study. Both descriptive and inferential statistics such as percentages, frequencies counts, multiple regression, and correlation analysis were used to analyse the data collected. The sample used was 120 professionals but only 80 returned responses were used for analysis. The study concluded that fraud or scandals that a company involved is as a result of several factors like unethical behaviors, agency problem, and non-professional attitude. It was also revealed that Creative accounting plays a significant role in the financial reporting of a company however it is negatively correlated because the more managers involved in it, the more the value of financial information decreases.

Bhasin (2016) carried out a study on the Survey of creative accounting practices: an exploratory study of an Asian Market in Malaysia. The study was descriptive research. The population of the study comprised all the preparers and users of the corporate Financial Statement. The sample of 120 people was randomly selected for the study. The study questionnaire was the major instrument used to collect data for the study. From the distributed questionnaire only 85 returned from the participants and subjected to analysis using the percentage and frequencies of respondents. The findings of the study showed that the practice of Creative Accounting is always a deliberate attempt to gain an undue advantage for accountants, managers, and companies.

Ismael (2018) in his study examined to establish the impact of creative accounting techniques on the reliability of financial reporting with particular reference to Saudi auditors and academics in Al-Kharj, Saudi Arabia. The study was descriptive research. The questionnaire of the five-point Likert scale was used for the study. The researcher distributed 100 questionnaires randomly to some practitioners of the accounting and auditing profession in the KSA environment but only 63 respondents returned. The data were analysed using both descriptive and inferential statistics. The result of the finding concluded that creative accounting RESULTS

Table 1: Percentage scores on the awareness of the term creative accounting

\begin{tabular}{ccc}
\hline & Frequency & Percentage \\
\hline Yes & 54 & $90 \%$ \\
No & 6 & $10 \%$ \\
\hline
\end{tabular}

The result in table 1 indicated that $54(90 \%)$ of the respondents were aware of the term creative accounting while only $6(10 \%)$ claimed to be unaware. Thus, this techniques used by management negatively affect the reliability of financial reporting.

Akenbor, and Ibanichuka, (2012) investigated the Creative accounting practices in Nigerian Banks. The study adopted descriptive research of a survey type. The population of the study was fifty (50) branch managers and accountants of banks currently operating in the Federal Capital Territory (FCT) Abuja as at the time the study was conducted. A five-point Likert scale questionnaire was the instrument used to elicit responses for the study. The data collected for the study were analysed descriptively using mean scores while the formulated hypotheses were tested with Z-test and Analysis of Variance (ANOVA). The findings of the study revealed that the only major reason for creative accounting practices in Nigerian banks is to boost the market value of shares. The study further revealed that users of accounting information are adversely affected by the practice of creative accounting.

\section{METHODOLOGY}

The descriptive research of a survey type was adopted. The population of the study comprises 187 accounting educators (academic staff) and practitioners in Afe Babalola University, Ado Ekiti and Federal Polytechnic, Ado Ekiti. The sample of the study was 60 respondents selected using a purposive random sampling technique. A well-structured questionnaire was the instrument used for the study and the face validity of the instrument was ensured by the experts in the Department of Accounting. The reliability of the instrument was determined through a pilot-test conducted on the instrument. The reliability coefficient of 0.85 was obtained using the Cronbach alpha coefficient which indicated that the instrument was reliable to collect all the necessary data for the study. The research questions were answered using mean scores and standard deviation and ANOVA was used to test the hypotheses formulated at 0.05 level of significance.

shows that $90 \%$ of the respondents have the knowledge of the subject matter which means the data got from the available respondents are enough for the study. 


\section{EPRA International Journal of Research and Development (IJRD)}

Volume: 6 | Issue: 3 | March 2021

- Peer Reviewed Journal

Table 2: Mean scores and standard deviation on the creative accounting techniques used to influence accounting information

\begin{tabular}{llllll}
\hline S/N & Items & N & Mean & St.D & Remarks \\
\hline 1 & Enter artificial transactions to the financial statement & 60 & 3.27 & 0.70 & Agreed \\
2 & Change of the value and structure of internal capital & 60 & 3.08 & 0.64 & Agreed \\
3 & Change of the value of assets & 60 & 3.43 & 0.62 & Agreed \\
4 & Change of the value of liabilities & 60 & 3.13 & 0.85 & Agreed \\
5 & $\begin{array}{l}\text { Reclassification and presentation of assets or liabilities } \\
6\end{array}$ & 60 & 3.43 & 0.56 & Agreed \\
& $\begin{array}{l}\text { Overestimation of revenue by recording fictitious sales } \\
\text { revenue }\end{array}$ & 60 & 2.52 & 0.96 & Agreed \\
7 & $\begin{array}{l}\text { Change the value and structure of revenues } \\
\text { Off-balance sheet financing to enable company show better }\end{array}$ & 60 & 2.71 & 1.02 & Agreed \\
& $\begin{array}{l}\text { gearing ratios } \\
\text { Grand Mean }\end{array}$ & & 3.57 & 0.67 & Agreed \\
& & & & & \\
\hline
\end{tabular}

The result in table 2 revealed that items 1-8 are rated above the acceptable mean score of 2.50 which indicated that respondents agreed with all the statements. The grand mean and standard deviation of 3.14 and 0.75 further revealed that there was a high reaction from the respondents on the creative accounting techniques used to influence accounting information. Thus, it implies that accounting educators (academic staff) and practitioners could identify creative accounting techniques used to influence accounting information.

Table 3: Percentage scores on the extent to which practices of creative accounting affect the characteristics of accounting information

\begin{tabular}{lll}
\hline Category & Frequency & Percentage \\
\hline Low $(1.00-1.49)$ & 6 & $10 \%$ \\
Moderate $(1.50-1.99)$ & 10 & $16.67 \%$ \\
High $(2.00-3.00)$ & 44 & $73.33 \%$ \\
Total & $\mathbf{6 0}$ & $\mathbf{1 0 0} \%$ \\
\hline
\end{tabular}

In order to determine the extent to which practices of creative accounting affect the characteristics of accounting information, mean values of responses towards characteristics of accounting information were used. Mean values were used to illustrate the responses to items 9-16 in the questionnaire on the perception of accounting educators and practitioners towards the practices of creative accounting and categorized into low, moderate and high.

Respondents who scored below the mean score (2.50) were categorized into low extent. Those who scored above the mean score were categorized into high extent while those who scored around the mean score were grouped as moderate. The extent to which practices of creative accounting affect the characteristics of accounting information is presented in table 3 .

The result showed that out of 60 respondents, $6(10 \%)$ indicates low practices of creative accounting, 10 $(16.67 \%)$ showed moderate practices of creative accounting while those who indicated high practices of creative accounting were $44(73.33 \%)$. This shows that the extent to which the practices of creative accounting affect the characteristics of accounting information is high. 
Table 4: Mean scores and standard deviation on opinions of accounting educators and practitioners toward the practices of creative accounting

\begin{tabular}{|c|c|c|c|c|c|}
\hline & Items & $\mathbf{N}$ & Mean & St.D & Remarks \\
\hline 17 & $\begin{array}{l}\text { Accounting/audit profession is affected by creative } \\
\text { accounting }\end{array}$ & 60 & 3.43 & 0.78 & Agreed \\
\hline 18 & $\begin{array}{l}\text { Creative accounting affects the level of accuracy of } \\
\text { accounting information }\end{array}$ & 60 & 2.70 & 1.03 & Agreed \\
\hline 19 & $\begin{array}{l}\text { Creative accounting devalues the integrity of accounting } \\
\text { practitioners }\end{array}$ & 60 & 2.71 & 1.22 & Agreed \\
\hline 20 & $\begin{array}{l}\text { Creative accounting affects the level of credibility of } \\
\text { accountants and auditors that prepare and audit } \\
\text { accounting information }\end{array}$ & 60 & 3.48 & 0.57 & Agreed \\
\hline 21 & $\begin{array}{l}\text { Creative accounting practices affect the image of } \\
\text { accounting profession as a whole }\end{array}$ & 60 & 3.28 & 0.78 & Agreed \\
\hline 22 & $\begin{array}{l}\text { Creative accounting practices affect the users' } \\
\text { confidence on accounting information }\end{array}$ & 60 & 3.08 & 0.87 & Agreed \\
\hline 23 & $\begin{array}{l}\text { Creative accounting practices lead to alarming rate of } \\
\text { corruption in the business environment }\end{array}$ & 60 & 2.90 & 1.20 & Agreed \\
\hline 24 & $\begin{array}{l}\text { Creative accounting practices affect the quality of } \\
\text { accounting information in making investment decision }\end{array}$ & 60 & 3.42 & 0.67 & Agreed \\
\hline & Grand Mean & & 3.12 & 0.89 & Agreed \\
\hline
\end{tabular}

The result in table 4 revealed that items $17-24$ rated above the acceptable mean score of 2.50 , which indicated respondents' agreement with all the statements, this means the opinions of accounting educators and practitioners toward the practices of creative accounting are negative. The grand mean and standard deviation of 3.12 and 0.89 further indicated that there was a high reaction from the respondents on the opinions of accounting educators and practitioners toward the practices of creative accounting.

\section{Test of Hypotheses}

$\mathrm{H}_{\mathrm{O} 1}$ : There is no significant difference between accounting educators and practitioners' responses on creative accounting techniques used

Table 5: ANOVA showing difference between accounting educators and practitioners' responses on creative accounting techniques

\begin{tabular}{lrrrrr}
\hline & $\begin{array}{c}\text { Sum of } \\
\text { Squares }\end{array}$ & Df & $\begin{array}{c}\text { Mean } \\
\text { Square }\end{array}$ & F & Sig. \\
\hline Between Groups & 2.765 & 2 & 1.3825 & 2.375 & 0.224 \\
Within Groups & 32.5625 & 57 & 0.57125 & & \\
Total & 35.3275 & 59 & & & \\
$P>0.05$ level of significant. & & & & &
\end{tabular}

The results in table 5 shows that $\left(\mathrm{Df}_{2,57}=2.375\right.$, $<\mathrm{F}_{\mathrm{t}}=3.00$ at 0.05 ) is not significant. Thus, the null hypothesis was accepted. This implies that there is no significant difference between accounting educators and practitioners' responses on creative accounting techniques. The implication of this result is that both accounting educators and practitioners are aware of the creative accounting technique used to influence accounting information.

$\mathrm{H}_{\mathrm{O} 2}$ : There is no significant difference between accounting educators and practitioners' responses on the extent to which creative accounting practices affect the characteristics of accounting information 


\section{EPRA International Journal of Research and Development (IJRD)}

Table 6: ANOVA showing difference in accounting educators and practitioners' responses on the extent to which creative accounting practices affect the characteristics of accounting information

\begin{tabular}{lrrrrr}
\hline & $\begin{array}{c}\text { Sum of } \\
\text { Squares }\end{array}$ & Df & $\begin{array}{c}\text { Mean } \\
\text { Square }\end{array}$ & F & Sig. \\
\hline Between Groups & 0.8485 & 2 & 0.424 & 0.974 & 0.436 \\
Within Groups & 24.6265 & 57 & 0.432 & & \\
Total & 25.475 & 59 & & & \\
\hline
\end{tabular}

$\mathrm{P}>0.05$ level of significant.

The results in table 6 shows that $\left(\mathrm{Df}_{2,57}=0.974\right.$, $<\mathrm{F}_{\mathrm{t}}=3.00$ at 0.05$)$ is not significant. Thus, the null hypothesis was accepted. This implies that there is no significant difference in accounting educators and practitioners' responses on the extent to which creative accounting practices affect the characteristics of accounting information. Therefore, academic staff and accounting practitioners believed that practices of creative accounting affect the characteristics of accounting information to a high extent.

$\mathrm{H}_{\mathrm{O} 3}$ : There is no significant difference between accounting educators and practitioners' responses on the opinion toward the practices of creative accounting

Table 7: ANOVA showing difference in accounting educators and practitioners' responses on the opinion toward the practices of creative accounting

\begin{tabular}{lrrrrr}
\hline & Sum of Squares & Df & \multicolumn{1}{c}{$\begin{array}{c}\text { Mean } \\
\text { Square }\end{array}$} & F & Sig. \\
\hline Between Groups & 7.7748 & 2 & 1.3875 & 1.728 & 0.171 \\
Within Groups & 47.1315 & 57 & 0.8268 & & \\
Total & 54.9063 & 59 & & & \\
\hline
\end{tabular}

$\mathrm{P}>0.05$ level of significant.

The results in table 7 shows that $\left(\mathrm{Df}_{2,57}=1.728\right.$, $<\mathrm{Ft}=3.00$ at 0.05$)$ is not significant. Hence, the null hypothesis was accepted. Thus, there is no significant difference between accounting educators and practitioners' opinions toward the practices of creative accounting. The implication of this is that the practices of creative accounting affect accounting information.

\section{DISCUSSION OF FINDINGS}

The findings of the study revealed various creative accounting techniques that are negatively affecting accounting information, this include; entering artificial transactions to the financial statement, change of the value and structure of internal capital, change of the value of assets and liabilities, reclassification and presentation of assets or liabilities, overestimation of revenue by recording fictitious sales revenue, changing the value and structure of revenues and off-balance sheet financing to enable company show better gearing ratios.

The findings of the study also revealed that practices of creative accounting affect the characteristics of accounting information to a very high extent. These characteristics include; reliability, relevance, verifiability, neutrality, completion, and faithful representations of accounting information. This study supported that of Ismael (2018), who found that creative accounting techniques used by management negatively affect the reliability of financial reporting.

Finally, the result of the study showed that the practices of creative accounting affect the integrity of accounting practitioners, level of credibility of accountants and auditors, the image of the accounting profession as a whole, the quality of accounting information, and users' confidence in accounting information. This study is in agreement with Akenbor and Ibanichuka (2012) who revealed that users of accounting information are adversely affected by the practice of creative accounting.

\section{CONCLUSION AND RECOMMENDATIONS}

From the findings of this study, the perceptions of accounting educators (academic staff) and practitioners are not different toward practices of creative accounting. Hence, accounting educators (academic staff) and practitioners are aware of the creative accounting technique used to influence accounting information. The study further revealed that practices of creative accounting affect all the characteristics of accounting information as well as users' investment decisions and the integrity of the practitioners. In conclusion, accounting educators and practitioners indicated that creative accounting is 


\section{SJIF Impact Factor 2021: 7.13| ISI I.F.Value:1.241| Journal DOI: 10.36713/epra2016 \\ ISSN: 2455-7838(Online) EPRA International Journal of Research and Development (IJRD)}

negatively affecting the accounting information and profession. Therefore, the study recommended that accounting bodies should take strict measures to curb creative accounting practices among accounting practitioners, to restore integrity and users' confidence in accounting information. Also, a monitoring team/group should be in place to check the draft of accounting information prepared by any organization/institution, this would be required in order to prepare a financial statement before being finally published for public consumption.

\section{REFERENCES}

1. Adetayo, J.A. \& Ajiga, O. F. (2017). Creative Accounting Practices among Nigeria Listed Commercial Banks: Curtailing Effect of IFRS Adoption, Journal of Resources Development and Management 38.54-63

2. Akenbor, C.O. \& Ibanichuka, A.E.L. (2012). Creative Accounting Practices in Nigerian Banks. African Research Review-International Multidisciplinary Journal, Ethiopia. 6(3), 23 - 41.

3. Al Momani, M.A., \& Obeidat, M.I. (2013). The effect of auditors' ethics on their detection of creative accounting practices: A field study. International Journal of Business and Management,8(13), 118-136.

4. Bankole, K. O., Ukolobi, I. O. \& McDubus, O. F. (2018). Creative Accounting Practices and Shareholders' Wealth. Accounting and Taxation Review2(4), 58-74.

5. Bhasin, M. L. (2016). Survey of Creative Accounting Practices: An Exploratory Study of an Asian Market. International Journal of Management and Social Sciences Research. 5(9) 29-31

6. Gaara, O.A. (2012). The external auditor methods to detect fraud in the financial statements. Journal of Business Studies. 2, 182-199.

7. Gabriëls, X. \& Van De Wiele, P. (2005) Creative Accounting: Ethical Perceptions among Accounting and Non-Accounting Students. Working paper

8. Ismael , A. Y. A. (2017). The Impact of Creative Accounting Techniques on the Reliability of Financial Reporting with Particular Reference to Saudi Auditors and Academics. International Journal of Economics and Financial Issues.7(2), 283-291.

9. Momani, M.A. \& Obeidat, M.I. (2013). The effect of auditors" ethics on their detection of creative accounting practices: a field study, International Journal of Business and Management. 8(13), 118135.

10. Oluwagbuyi, O. L \& Olowolaju, M. (2013). Incessant Financial Scandals in the Corporate Organizationsin, Nigeria: Auditors' Culpability. Research Journal of Finance and Accounting, 4(9) $104-109$.
11. Tassadaq, F. \& Malik, Q.A. (2015). Creative accounting and financial reporting: model development and empirical testing, International Journal of Economics and Financial Issues, 5(2), 544-551.

12. Victoria, F. (2014). An empirical study on the impact of creative accounting policies on the performance of listed Romanian companies. Valahian Journal of Economic Studies.5(4), 41-48.

13. Sanusi, B. \& Izedonmi, P.F. (2014). Nigerian Commercial Banks and Creative Accounting Practices, Journal of Mathematical Finance, 4, 7583.

14. Shah, S., Butt, S. \& Tariq, Y.B. (2011). Use or Abuse of Creative Accounting Techniques. International Journal of Trade, Economics and Finance, 2(6), 531-536.

15. Yadav, B. (2013). Creative accounting: a literature review. The SIJ Transactions on Industrial, Financial and Business Management (IFBM), 1(5), 181-193. 